\title{
Advances in vegetative propagation of Olive tree
}

\author{
Márcia Wulff Schuch ${ }^{1}$, Zeni Fonseca Pinto Tomaz ${ }^{2}$, Josiane Vergara Casarin ${ }^{3}$, \\ Roseane Maidana Moreira ${ }^{4}$, Jacqueline Barcelos da Silva ${ }^{5}$
}

\begin{abstract}
In Brazil, there is a growing interest in the crop of the olive tree, especially in those regions considered suitable for cultivation, where low temperatures occur between $8{ }^{\circ} \mathrm{C}$ and $10^{\circ} \mathrm{C}$ in the period before flowering. The areas with these characteristics are located mainly in the South and Southeast regions of the country, characterized by a temperate climate in function of altitude, with the occurrence of natural vernalization. The propagation is an integral part of the production chain and the first step towards the implantation of the olive tree crop or renovation of the existing orchards. Obtaining quality seedlings, besides guaranteeing uniformity and reliable varietal origin, is a factor that influences the whole life of the orchard, allowing to maximize the effects of climate and soil and mainly of crop treatments adopted for the culture. In the Laboratory of Propagation of Fruit Plants of the Department of Phytotechnology of the Eliseu Maciel School of Agronomy of the Federal University of Pelotas, we have sought to research micropropagation and minipropagation allied to the clonal gardens kept in a protected place, reducing the physical space and improving, mainly, the crop protection control. Olive tree seedlings propagated by different methods of asexual propagation, such as micropropagation, microcutting and minicutting, and they have their completion until the complete development in no-soil cultivation systems.
\end{abstract}

Index terms: seedlings, cloning, mini propagation and micro propagation, cultivation system without soil.

\section{Avanços na propagação vegetativa de Oliveira}

Corresponding author: marciaws@ufpel.tche.br zfptomaz@yahoo.com.br

Received: June 08, 2018

Accepted: September 21, 2018

Copyright: All the contents of this journal, except where otherwise noted, is licensed under a Creative Commons Attribution License.

\section{(cc) $\mathbf{E Y}$}

Resumo - No Brasil é crescente o interesse pela cultura da oliveira, especialmente naquelas regiões consideradas aptas ao cultivo, onde se têm ocorrência de baixas temperaturas entre $8^{\circ} \mathrm{C}$ e $10^{\circ} \mathrm{C}$ no período que antecede a floração. As áreas com estas características estão localizadas, principalmente, nas regiões Sul e Sudeste do país, caracterizadas por clima temperado em função da altitude, com ocorrência da vernalização natural. A propagação é parte integrante da cadeia produtiva e o primeiro passo para a implantação da cultura da oliveira ou renovação dos pomares já existentes. A obtenção de mudas de qualidade, além de garantir uniformidade e origem varietal confiável, é um fator que influencia toda a vida do pomar, permitindo maximizar os efeitos de clima e de solo e principalmente de tratos culturais adotados para a cultura. No Laboratório de Propagação de Plantas Frutíferas, do Departamento de Fitotecnia da Faculdade de Agronomia Eliseu Maciel da Universidade Federal de Pelotas tem-se buscado pesquisar, a micropropagação e a minipropagação aliado aos jardins clonais mantidos em local protegido, reduzindo o espaço físico e melhorando, principalmente, o controle fitossanitário. As mudas de oliveira propagadas por diferentes métodos de propagação assexuada, como micropropagação, microestaquia e miniestaquia tem sua finalização até o completo desenvolvimento em sistemas de cultivo sem solo.

Termos para indexação: plântulas, clonagem, mini-propagação e micro-propagação, sistema de cultivo sem solo. 
In Brazil, there is a growing interest in the crop of the olive tree, especially in those regions considered suitable for cultivation, where low temperatures occur between $8^{\circ} \mathrm{C}$ and $10^{\circ} \mathrm{C}$ in the period before flowering. The areas with these characteristics are located mainly in the South and Southeast regions of the country, characterized by a temperate climate in function of altitude, with the occurrence of natural vernalization.

With the increasing consumption of olive products and the current emphasis on the dissemination of the nutritional, dietary and organoleptic qualities of the extra-virgin olive oil, especially the monovarietal ones, with incomparable flavors and aromas, with low acidity, stimulate their raw consumption and use in salads (WREGE et al., 2015), it became necessary to raise olive tree productivity worldwide. For this, it is important to carry out studies that relate the development of the olive tree with environmental variables. This type of study is important, mainly, in regions that show different edaphiclimatic conditions of the regions of origin and cultivation, since it can have its development affected negatively, when cultivated outside its natural habitat (OLIVEIRA et al., 2012).

The propagation is an integral part of the production chain and the first step towards the implantation of the olive tree crop or renovation of the existing orchards. Obtaining quality seedlings, besides guaranteeing uniformity and reliable varietal origin, is a factor that influences the whole life of the orchard, allowing to maximize the effects of climate and soil and mainly of crop treatments adopted for the culture (OLIVEIRA et al., 2006).

The planting is recommended to be carrying out with high quality seedlings, which should be 12 to 16 months old, with a height of 80 to $100 \mathrm{~cm}$ with a single main stem, with the formation of the crown with up to four branches or limbs. This condition happens in properly managed nurseries, with irrigation use, supply of nutrients and the preventive control of pests and diseases (OLIVEIRA et al., 2003; VIEIRA NETO et al., 2010).

In the Laboratory of Propagation of Fruit Plants of the Department of Phytotechnology of the Eliseu Maciel School of Agronomy of the Federal University of Pelotas, we have sought to research micropropagation and minipropagation allied to the clonal gardens kept in a protected place, reducing the physical space and improving, mainly, the crop protection control. Olive tree seedlings propagated by different methods of asexual propagation, such as micropropagation, microcutting and minicutting, and they have their completion until the complete development in no-soil cultivation systems (SCHUCH and PEIL, 2012).

The rejuvenating capacity that the micropropagation provides can be used in the production of olive tree seedlings as an initial process, using from there the microcutting (vegetative propagation technique in which rejuvenated propagules (microcuttings) are used in a micropropagation laboratory, and later to be rooted, in order to maximize seedling production). The technique of minicutting follows the same precepts of the microcutting, however, the laboratory phase is eliminated. In minicutting, the initial strains are formed of seedlings propagated by conventional cuttings, whereas in the technique of the microcutting, the clonal garden is formed by strains that originate from micropropagated seedlings.

The propagation and growth of Arbequina olive cultivars were studied by CAPPELLARO (2013) at different seasons of the year, growth regulator concentrations, material collection environment and cultivation systems, along with the maintenance and rooting of minicuttings coming from nursery, through three experiments conducted in greenhouse and agricultural greenhouse at the Didactic and Experimental Campus of the Federal University of Pelotas. The experiment was carried out with the aim of evaluating the most suitable season for rooting, the influence of the environment where the matrix plants were located and the effect of different concentrations of IBA (indolebutyric acid) on the rooting of semi-woody cuttings of olive tree (Figure 1). The rooting was tested in three seasons (spring, winter and summer), material collection environment (greenhouse and open field) and five concentrations of IBA $(0,1000,2000,3000$ and 4000 $\left.\mathrm{mg} . \mathrm{L}^{-1}\right)$. The minicuttings of each culture environment of the matrix plants were collected and standardized with two pairs of buds and a pair of half leaves and later placed to rooting in plastic boxes with vermiculite of medium granulometry, after the preparation, they were placed in a greenhouse with temperature controlled at $25 \pm 2{ }^{\circ} \mathrm{C}$ for 80 days in the three seasons. The variables analyzed were: percentage of live minicuttings, percentage of rooted minicuttings, number of roots per minicuttings and length of roots. Minicuttings from greenhouse provided higher survival, rooting, number and length of roots. Spring was the season that, regardless of the collection environment, provided greater survival, rooting, number and length of the roots. The collection environment influenced the use of growth regulator. The use of material from open environment and regulator at $3000 \mathrm{mg} . \mathrm{L}^{-1}$ provided greater rooting. Materials collected in the spring and submitted to concentrations of 3000 and $4000 \mathrm{mg} . \mathrm{L}^{-1}$ produced higher number of roots (CAPPELLARO, 2013). 
After, the experiment was conducted with the aim of evaluating the growth of olive trees obtained by minicutting of Arbequina cultivar in systems of cultivation without soil and at different times (CAPPELLARO, 2013). The rooted minicuttings were planted to grow in three systems (no soil, NFT - Nutrient Film Technique and packing) (Figure 2), in two seasons (spring/summer and fall/winter) during five months of cultivation. In the soil-free system, the substrate used was sand, being daily irrigated with nutrient solution (Table 1). In the NFT system, the minicuttings were placed in phenolic foam which were irrigated through intermittent flow, three times a day for 5 minutes, and in the packaging system, the plants were grown in plastic bags filled with Carolina ${ }^{\circledR}$ substrate, with an average of $100 \mathrm{ml}$ of nutrient solution (Table 1 ) every 15 days. The variables analyzed were: number of growths, length of growths, number of secondary growths and length of secondary growths during the growing period, and after 150 days of cultivation the variables analyzed were: diameter of the stem, fresh and dry mass of the shoot, fresh and dry mass of the root. The use of the no-till cropping system and the season 2 of higher temperatures (spring/summer) provided higher plant growth.

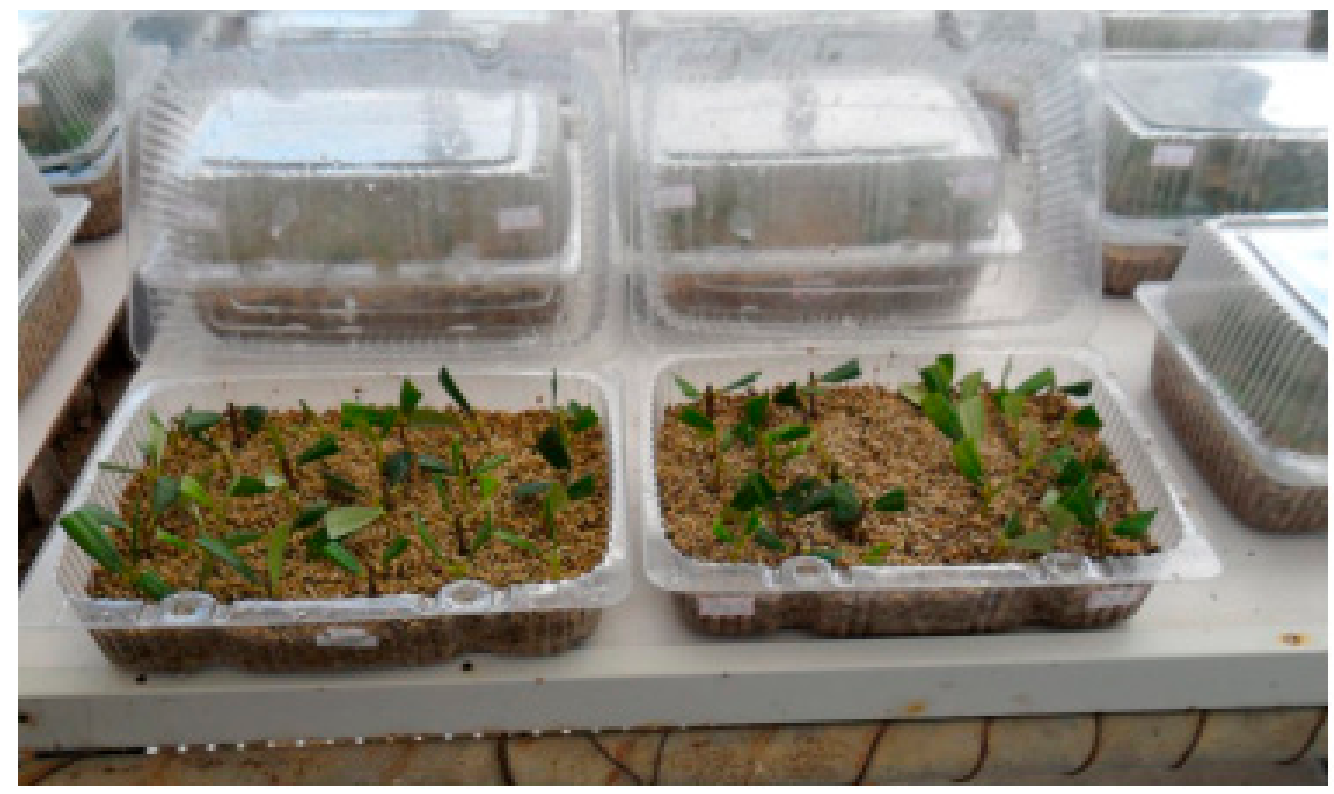

Figure 1 - Rooting of olive minicuttings of Arbequina cultivar in articulated plastic containers.

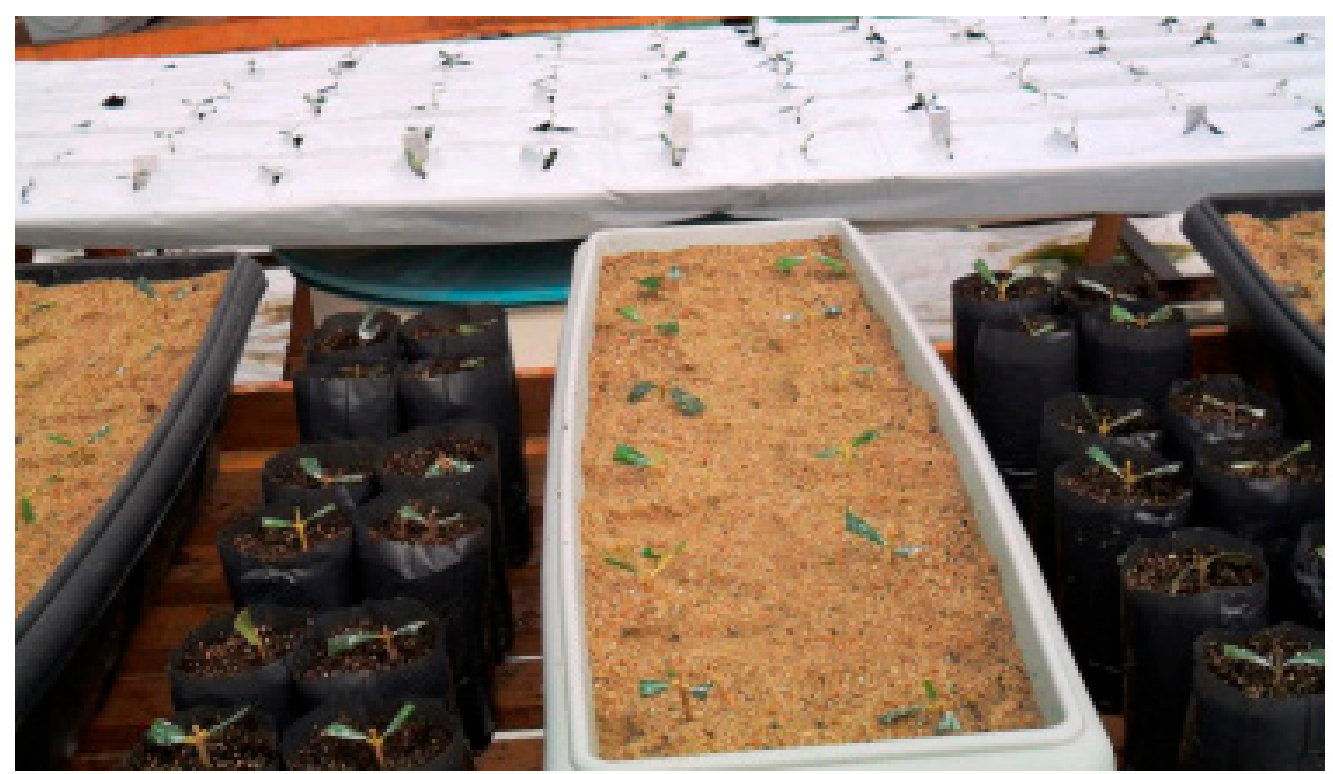

Figure 2 - Non-soil cultivation systems, NFT and packing. 
Table 1- Concentration of nutrient ions, electrical conductivity and $\mathrm{pH}$ of the nutrient solution developed by Schuch \& Peil for the olive tree and used in non-soil cultivation systems. UFPel, Pelotas, 2012.

\begin{tabular}{cc}
\hline Macronutrients & mmol $\mathbf{L}^{-1}$ \\
\hline NO3- & $14.4^{*}$ \\
H2PO4 - & 1.0 \\
SO42- & 2.8 \\
$\mathrm{NH} 4+$ & 1.1 \\
$\mathrm{~K}+$ & 3.3 \\
$\mathrm{Ca} 2+$ & 5.5 \\
$\mathrm{Mg} 2+$ & 2.8 \\
\hline Micronutrients & $\mathbf{m g ~ L}^{-1}$ \\
\hline $\mathrm{Fe}$ & 1.7 \\
$\mathrm{Mn}$ & 0.5 \\
$\mathrm{~B}$ & 0.3 \\
$\mathrm{Cu}$ & 0.5 \\
$\mathrm{Mo}$ & 0.1 \\
pH & 0.1 \\
Electrical conductivity & $2.1 \mathrm{dS} \mathrm{\textrm {m } ^ { - 1 }}$ \\
\hline
\end{tabular}

*calculated based on the mineral nutrient contents of olive tree seedlings.

Prepared by Schuch; Peil (2012)

CAPPELLARO (2013) also carried out an experiment with the aim of evaluating the rooting of olive tree minicuttings from matrices conditioned in cultivation systems without soil and packing systems, and to evaluate the nutrient content of these nurseries in two growing seasons (spring/summer and fall/winter). The matrix plants were found in three cropping systems, which were described in the previous experiment (Figure 3).The minicuttings were collected in winter and set to root according to the first experiment, but the IBA concentration was $3000 \mathrm{mg} \mathrm{L}^{-1}$. The variables analyzed after the 80 -day period were: percentage of minicuttings, percentage of rooted minicuttings, number of roots per minicuttings, length of roots and for the nutritional analysis, the contents of macronutrients and micronutrients and dry mass of shoot and root were evaluated. The use of the no-soil cultivation system associated with season 2 (spring/ summer) provided higher nutrient contents and produced higher dry matter contents of shoot and root.

The nutrient contents are the data obtained and calculated from the nutritional evaluation of the dry mass, based on foliar analysis of blueberry seedlings grown in a no-soil cultivation system. These were compared in previous study of constant data in the bibliography about the adequate concentration of nutrients in adult plants of blueberry tree cultivated in conventional system.

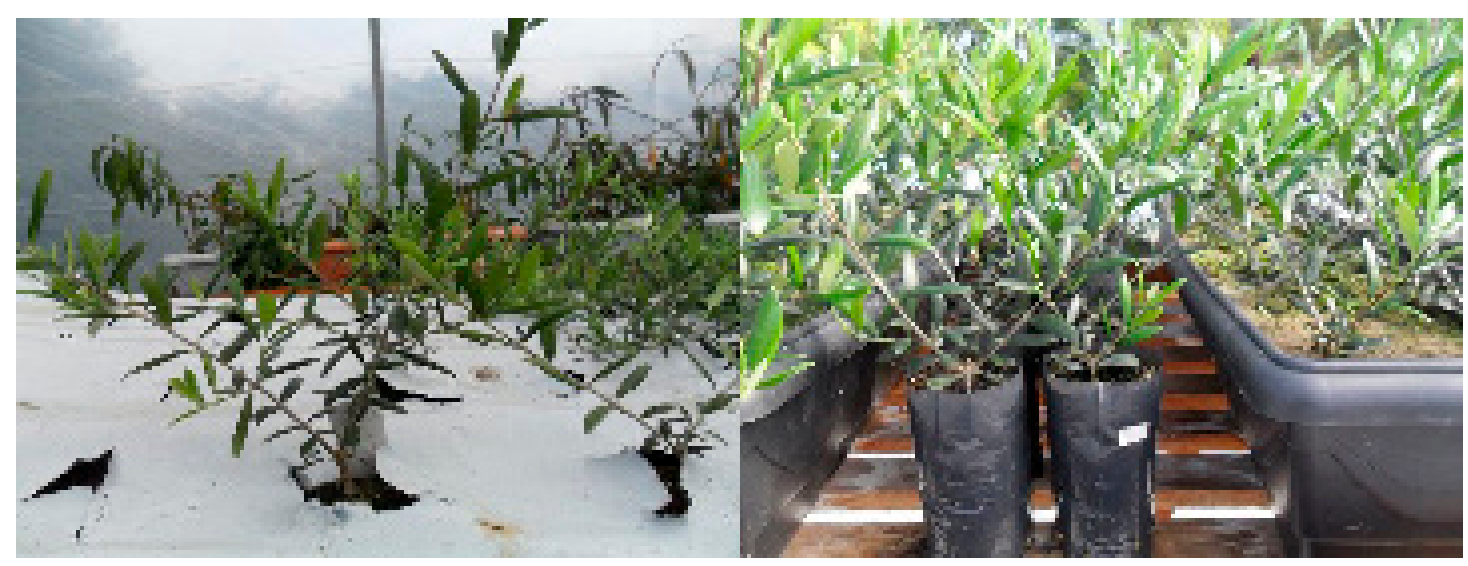

Figure 3 - Nursery of olive trees of Arbequina cultivar in NFT cultivation systems, without soil and packing. 
The increasing olive cultivation in tropical and temperate regions of the world demands technologies for the installation of orchards. Among the propagation techniques used for the olive tree, micropropagation stands out, as it allows to conserve the germplasm and to produce seedlings of high quality and sanity. However, there is a lack of efficient protocols for in vitro establishment of olive cultivars, since each genotype responds differently to micropropagation. Thus, MOREIRA (2014) aimed to develop efficient protocols for the reduction of oxidation and in vitro establishment of olive trees. In the in vitro establishment of six olive cultivars (Ascolano, Leccino, Maria da Fé, Coratina, Arbequina and Frantoio) in different growing medium (MO and WPM) and the explant collection seasons (fall, winter, spring and summer), the variables related to the percentage of oxidation were evaluated; fungal and bacterial contamination; survival and establishment of explants in vitro. The results obtained showed that there was more phenolic oxidation in olive explants collected in the winter. Spring can be indicated as the best season for the collection of explant of the Maria da Fé cultivar, while the Ascolano and Arbequina cultivars showed higher rate of in vitro establishment when collected the explants in the fall. The WPM growing medium promoted a higher percentage of establishment of olive explants, independent of the studied season (Figure 4).

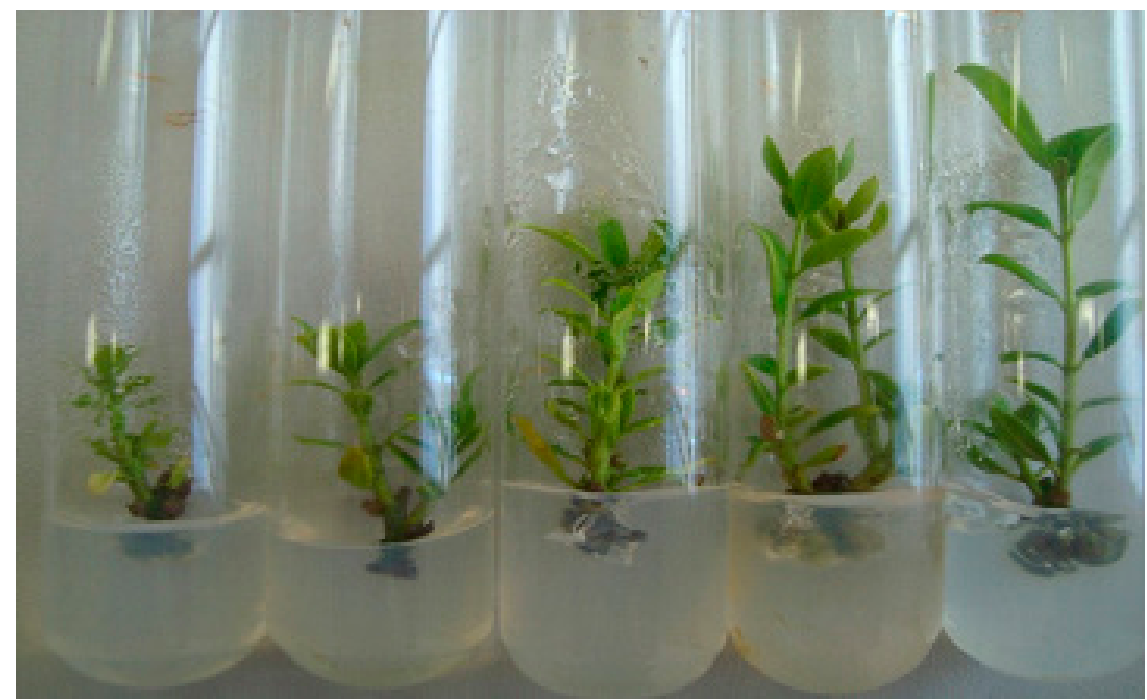

Figure 4 - Olive explants established at 45 days of in vitro crop.

MOREIRA (2014), with the aim of evaluating the effect of the presence and absence of light supplied to the matrix plant, as well as the zeatin concentrations $(0$, 2, 4 and $\left.8 \mathrm{mg} . \mathrm{L}^{1}\right)$ in the in vitro establishment, evaluated the variable related to the percentage of oxidation; fungal and bacterial contamination; survival and establishment of explants in vitro. In this experiment, the matrix plants under conditions of absence of light were indicated in the in vitro establishment of the studied Arbequina cultivar. The concentration of $2 \mathrm{mg} . \mathrm{L}^{-1}$ of Zeatin favors the survival of Arbequina olive explants. The concentrations (0, 4 and $\left.8 \mathrm{mg} . \mathrm{L}^{-1}\right)$ of Zeatin showed no difference between the Leccino and Arbequina cultivars for the fungal contamination variable (Figure 5).

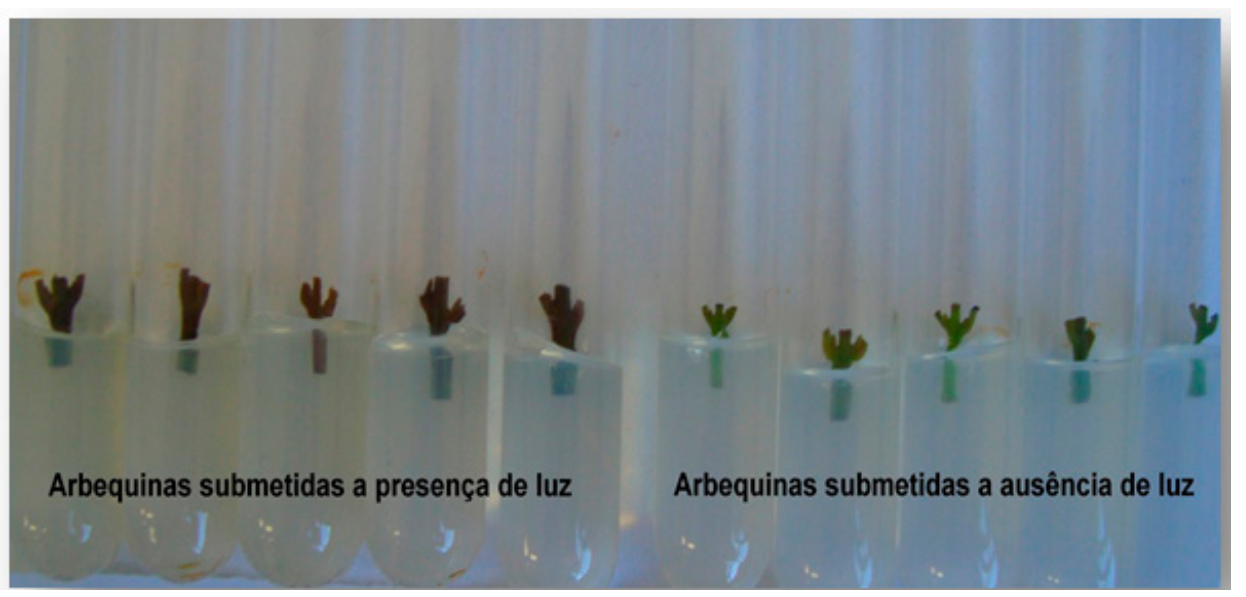

Figure 5 - Olive explants of Arbequina from plants submitted to the presence of light showed oxidation symptoms at 14 days of in vitro cultivation (left), the explants from matrix plants submitted to absence of light, remained green (right). 
The production of seedlings by minicutting is a method of vegetative propagation and has recently been tested for olive cultivation. CASARIN (2015) evaluated the effects of different concentrations of indolebutyric acid (IBA) $\left(0,1000,2000\right.$ and $\left.3000 \mathrm{mg} \cdot \mathrm{L}^{-1}\right)$ on minicutting rooting of six olive cultivars (Ascolano 315, Coratina, Frantoio, Grappolo 541, Leccino and Maria da Fé). After the material collection, minicuttings were prepared, with $3-5 \mathrm{~cm}$, two pairs of buds and the leaves had their area reduced by $50 \%$. At the base of the cuttings, two superficial lesions were performed and then immersed for ten seconds in IBA acid solution at concentrations of 0 (free of IBA), 1000, 2000 and $3000 \mathrm{mg} . \mathrm{L}^{-1}$ and placed in transparent plastic articulated boxes with Sampack ${ }^{\circledR}$ cover, with medium expanded vermiculite substrate. Afterwards, they were conditioned in a greenhouse with controlled temperature at $25 \pm 2^{\circ} \mathrm{C}$ for 60 days. After this period, the following variables were evaluated: percentage of survival and rooting, number of shoots and roots and length of roots by minicuttings $(\mathrm{cm})$.
The olive cultivars showed different responses in the evaluated variables when submitted to IBA concentrations, and the use of IBA did not influence the survival of minicuttings, except for the Leccino cultivar in the absence of IBA and with $3000 \mathrm{mg} \cdot \mathrm{L}^{-1}$ of IBA.

According to the results obtained in the absence of IBA, the highest rooting percentage was observed in the Maria da Fé cultivar with $95 \%$ and Ascolano 315 with $87.50 \%$. At the concentration of $1000 \mathrm{mg} . \mathrm{L}^{-1}$ of IBA, the best percentages of rooting were observed in the Maria da Fé, Leccino, Grappolo 541 and Coratina cultivars with $100 \%, 95 \%, 93.75 \%$ and $93.75 \%$, respectively. The highest percentages of rooting were observed in the $2000 \mathrm{mg} . \mathrm{L}^{-1}$ IBA, with Maria da Fé (98.75\%), Leccino and Grappolo 541 with $95 \%$. At the highest IBA concentration (3000 mg. $\left.\mathrm{L}^{-1}\right)$, the cultivars with the highest rooting percentages were Grappolo 541 (98.75\%) and Ascolano 315 (96.25\%). In this way, it was possible to verify that the olive minicuttings showed high rooting percentages and each cultivar responds differently to the IBA concentrations used (Figure 6).

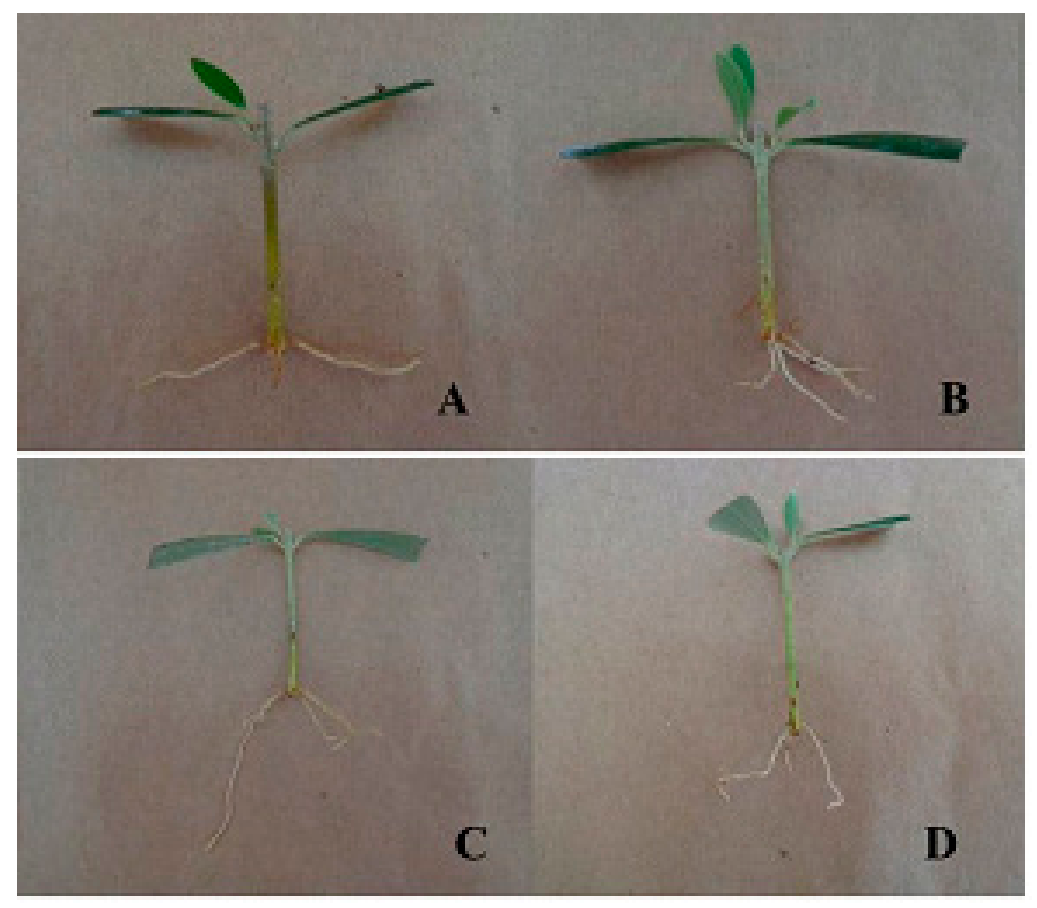

Figure 6 - Rooting of Maria da Fé cultivar submitted to treatment with IBA concentrations. A) with IBA, B) 1000 mg. $L^{-1}$ of IBA, C) $2000 \mathrm{mg} . \mathrm{L}^{-1}$ of IBA, D) $3000 \mathrm{mg} . \mathrm{L}^{-1}$ of IBA. 
The adjustment of models, which express the rooting of the different genetic materials to be propagated in a nursery, can minimize the costs, due to the optimization of the use of the facilities, avoiding the permanence of seedlings in the greenhouse beyond the necessary time, or the death of minicuttings as a function of their removal before the rhizogenic process is completed (MELO et al., 2011).

Thus, Casarin (2015), in order to optimize the time of rooting of olive minicuttings, carried out an experiment to evaluate the time required for the rooting of minicuttings of six olive cultivars by monitoring the emission and development of roots. The cultivars used in this study were: Arbequina, Ascolano 315, Coratina, Frantoio, Grappolo 541 and Leccino.
For the necessary time of rooting, the minicuttings were prepared in the same way as described by Casarin (2015), using the concentration of $3000 \mathrm{mg} . \mathrm{L}^{-1}$ of IBA. After the minicuttings were prepared, they were kept in a greenhouse at $25 \pm 2^{\circ} \mathrm{C}$. The evaluations were performed at $14,21,28,35,42$ and 49 days, when the percentage of survival and rooting, number and length of roots $(\mathrm{cm})$ of minicuttings were verified. After the evaluations, the minicuttings were discarded.

The existence of differences in the rhizogenic process of minicuttings of the six olive cultivars evaluated was verified. The time required for rooting is different among cultivars. The best rooting rates were 28 days for Leccino (85\%) and Grappolo 541 (95\%) cultivars, at 35 days for Ascolano 315, Frantoio and Grappolo 541, with $85 \%, 90 \%$ and $95 \%$, respectively, at 42 days for Coratin $(60 \%)$ and at 49 days for Arbequina, with $80 \%$ of rooting (Table 2 and Figure 7).

Table 2 - Rooting percentage of olive tree minicuttings for the evaluation days.

\begin{tabular}{ccccccc}
\hline \multicolumn{7}{c}{ Evaluations day } \\
\hline Cultivars & 14 & 21 & 28 & 35 & 42 & 49 \\
\hline Arbequina & $5 \mathrm{~A}$ & $5 \mathrm{C}$ & $35 \mathrm{~B}$ & $35 \mathrm{BC}$ & $65 \mathrm{AB}$ & $80 \mathrm{~A}$ \\
Ascolano 315 & $0 \mathrm{~A}$ & $20 \mathrm{BC}$ & $20 \mathrm{BC}$ & $85 \mathrm{~A}$ & $40 \mathrm{BC}$ & $30 \mathrm{BC}$ \\
Coratina & $0 \mathrm{~A}$ & $20 \mathrm{BC}$ & $5 \mathrm{C}$ & $55 \mathrm{~B}$ & $60 \mathrm{AB}$ & $50 \mathrm{~B}$ \\
Frantoio & $0 \mathrm{~A}$ & $0 \mathrm{C}$ & $20 \mathrm{BC}$ & $90 \mathrm{~A}$ & $25 \mathrm{C}$ & $25 \mathrm{BC}$ \\
Grappolo 541 & $0 \mathrm{~A}$ & $55 \mathrm{~A}$ & $95 \mathrm{~A}$ & $95 \mathrm{~A}$ & $70 \mathrm{~A}$ & $80 \mathrm{~A}$ \\
Leccino & $5 \mathrm{~A}$ & $40 \mathrm{AB}$ & $85 \mathrm{~A}$ & $25 \mathrm{C}$ & $45 \mathrm{ABC}$ & $10 \mathrm{C}$ \\
\hline
\end{tabular}

Capital letters in the column differ from each other by the Tukey test at $5 \%$ probability error.

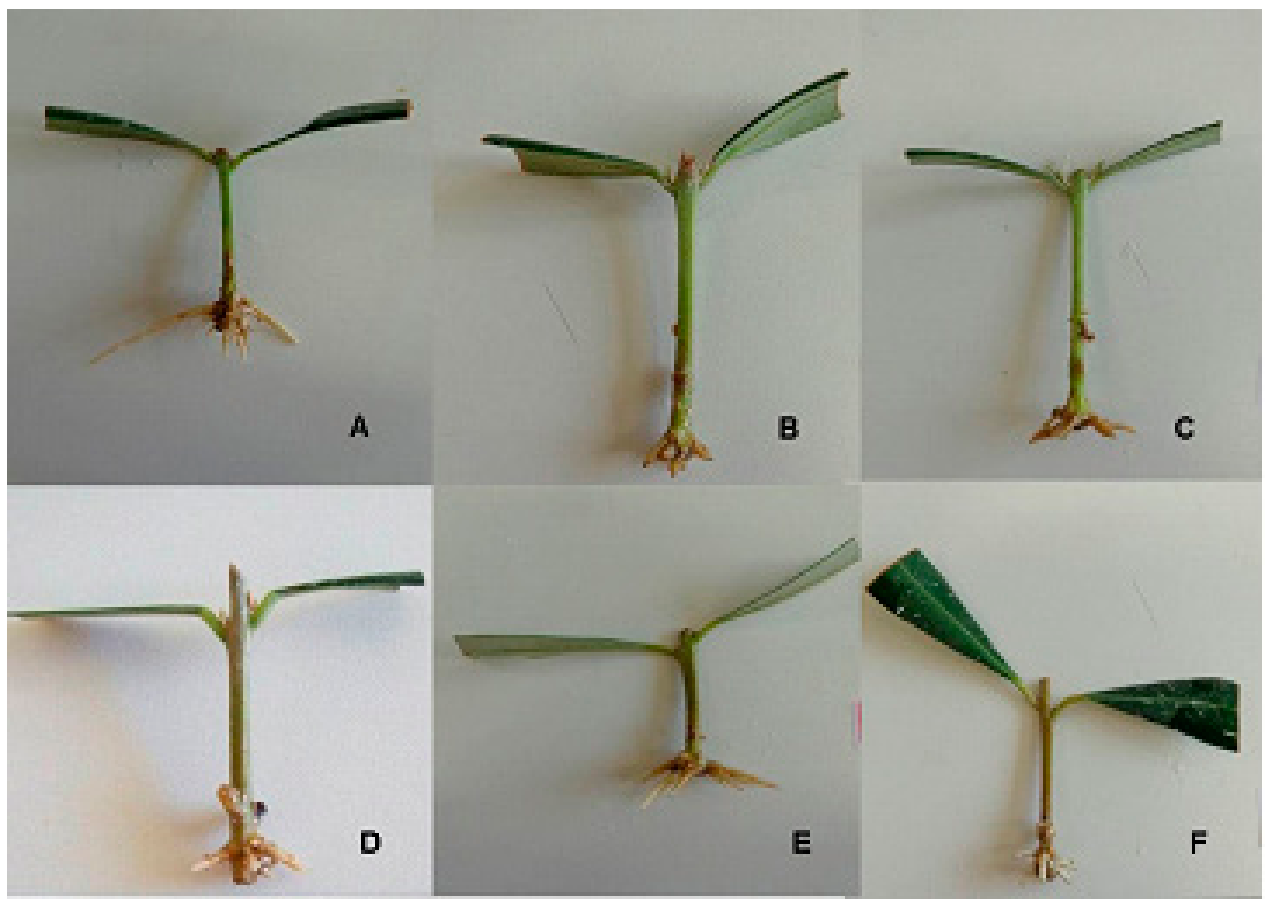

Figure 7 - Root development at 35 days of evaluation: Ascolano 315 (A), Leccino (B), Coratina (C), Arbequina (D), Grappolo 541 (E) and Frantoio (F). 
The production of seedlings is an important link in the production chain, since it constitutes the first step towards the implantation of the olive tree crop. Obtaining quality seedlings, besides guaranteeing uniformity and reliable varietal origin, is a factor that influences the whole life of the orchard, allowing to maximize the effects of climate and soil and mainly of crop treatments adopted for the culture (OLIVEIRA et al., 2010). One of the alternatives for the production of cuttings that has been widely used in fruit trees among them, the olive tree, is the use of clonal gardens.

In this way, Casarin (2015) developed a study with the aim of evaluating the productivity of olive ministumps of Arbequina cultivar during successive collections, in a semi-hydroponic and conventional cultivation system and the rooting of minicuttings collected at different seasons of the year of clonal garden cultivated in a semi-hydroponic and conventional cultivation system.

The clonal garden was formed in two cultivation systems: semi-hydroponic and conventional (Figure 8). The semi-hydroponic system was formed by trapezoidalshaped flower boxes with dimensions of $35 \mathrm{~cm}$ high $\mathrm{x}$ $27 \mathrm{~cm}$ wide $\mathrm{x} 72 \mathrm{~cm}$ length with a volume of 82.8 liters, filled with a $5 \mathrm{~cm}$ layer of medium gravel on the bottom and on this substrate sand of medium granulometry. The ministumps used were produced by rooting minicuttings. The system was constituted by 12 ministumps in flowerpot with spacing of $0.10 \times 0.10 \mathrm{~cm}$. Daily, the seedlings were manually irrigated with the aid of a watering can with approximately one liter of nutrient solution (Table 1) per flower box formulated by Schuch \& Peil (2012), according to the needs of the olive tree.

In the conventional system, the ministumps were placed in polyethylene plastic bags containing Carolina Soil ${ }^{\circledR}$ commercial substrate. The ministumps were individually distributed in each $10 \times 20 \mathrm{~cm}$ plastic bag, with a volume capacity of approximately $700 \mathrm{~mL}$, spaced $0.10 \times 0.10$. Daily, the seedlings were manually irrigated with a watering can with approximately $100 \mathrm{~mL}$ of rainwater per pack and every 15 days a nutrient solution was provided (Table 1).The Arbequina ministumps used in the two cultivation systems were transplanted with 80 days of rooting.

The study was divided in two stages described below:

In the first stage, the initial growth of the ministumps was evaluated at 30,60 and 90 days of cultivation in both systems, by the number of primary and secondary shoots and length of primary and secondary shoots, measured with a ruler graduated in centimeters.

In the second stage the material was collected in the clonal garden. During the experiment conduction period, the productivity of each clonal garden obtained in the seven collections was evaluated for the semi-hydroponic culture system and five collections for the conventional system, when the buds collected by ministumps were collected in each cultivation system. The plant material was collected in the crop systems every 90 days, with the exception of the winter period for the conventional cultivation system that there was no collection. The collections were carried out in the fall, winter and spring of 2013 and summer, fall, winter and spring of 2014 for the semi-hydroponic system. In the conventional system, the collections were carried out in the fall and spring of 2013 and summer, fall and spring of 2014.

After the material collection, minicuttings were prepared as previously described by Casarin (2015), the stakes were immersed in the concentration of $3000 \mathrm{mg} . \mathrm{L}^{-1}$ of IBA and conditioned in a greenhouse with controlled temperature at $25 \pm 2^{\circ} \mathrm{C}$ for 80 days. After this period, the following variables were evaluated: percentage of survival and rooting, number of roots and length of roots by minicuttings $(\mathrm{cm})$.

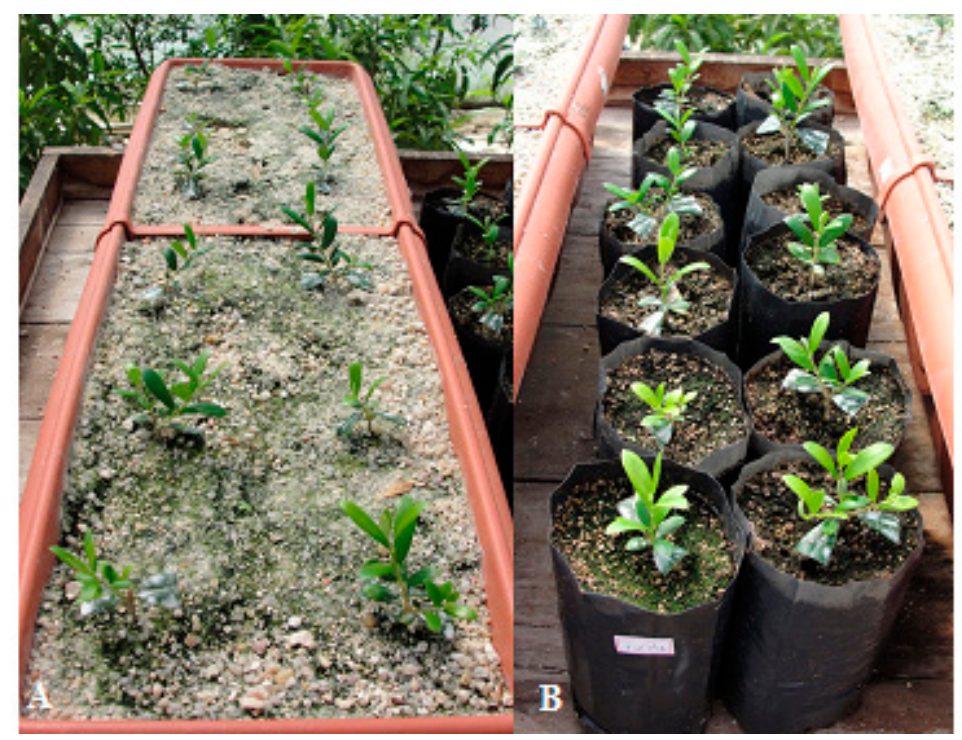

Figure 8 - Formation of the olive clonal garden of Arbequina cultivar at 30 days. A) Semi-hydroponic system and B) Conventional system. 
According to the results, it was possible to verify that until the 90 days (Figure 9) the olive ministumps of Arbequina cultivar showed a better initial development in the semi-hydroponic system compared to the conventional system.

The rooting percentage variable obtained high values in the winter and spring of 2014 with 98.5 and $92.5 \%$ in the semi-hydroponic cultivation system. In the conventional cultivation system, the fall of 2014 obtained
$80 \%$ of rooting, being the season of the year with the best result for this variable. The productivity of minicuttings during the harvest period was more efficient in the semihydroponic cultivation system, allowing successive collections during the evaluation seasons. In addition, the minicuttings collected in a semi-hydroponic system at most collection seasons showed a higher percentage of survival, rooting, number of growths and roots and length of roots, comparing to the conventional system.

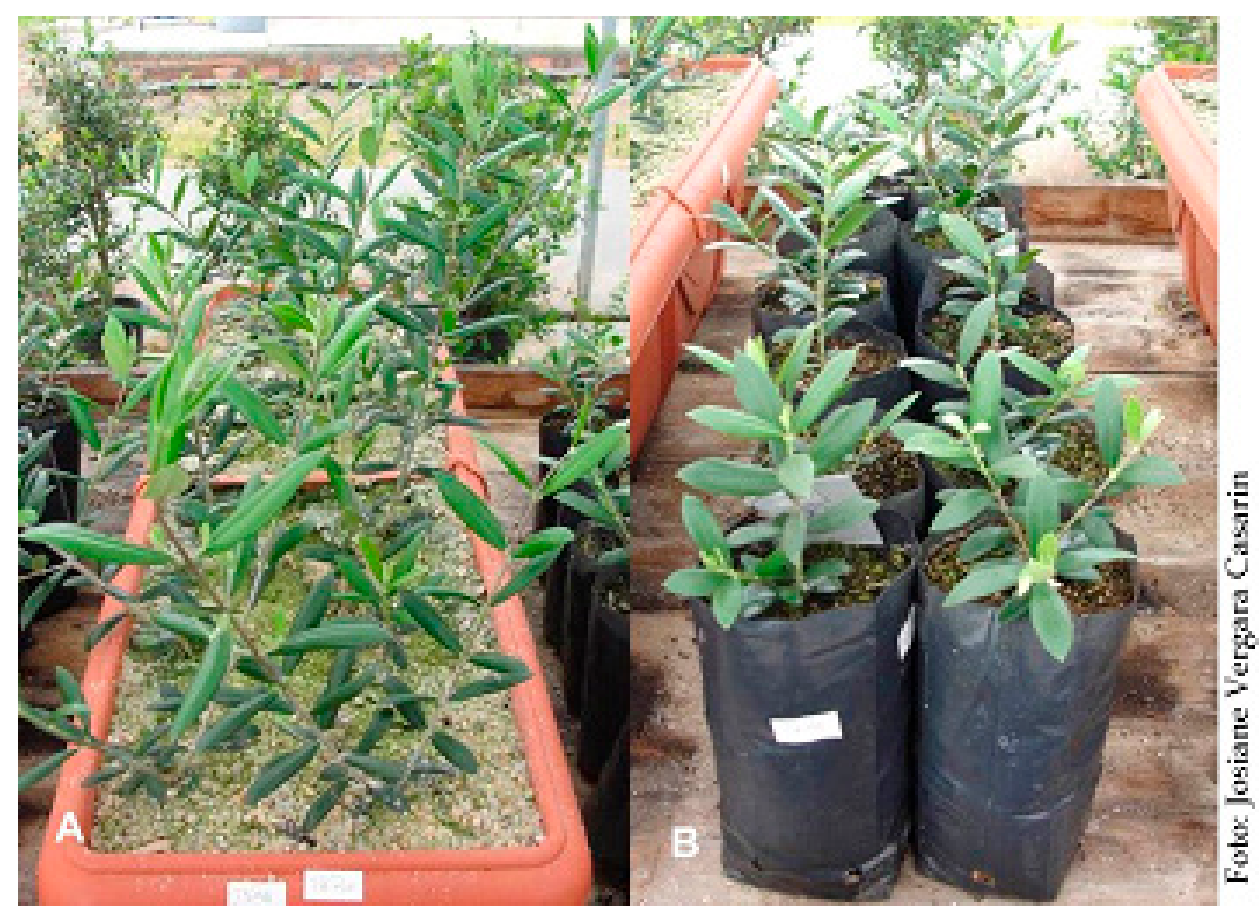

Figure 9 - Formation of the olive clonal garden of Arbequina cultivar at 90 days. A) Semi-hydroponic system and B) Conventional system.

According to FACHINELLO et al., 2005, the formation of seedlings in the shortest time and with maximum vigor depends on the characteristics of the substrate, which plays an important role in the growth of the plant, guaranteeing through its solid phase the growth of the shoot and the development of the root system (ZIETEMANN \& ROBERTO, 2007).

Casarin (2015), with the aim of evaluating the development of olive tree seedlings of Arbequina cultivar in different substrates obtained from rooting of minicuttings, verified the growth of olive tree seedlings of Arbequina cultivar in sand and coconut fiber substrates.

The minicuttings from the rooting of the clonal garden were planted in black polyethylene bags with dimensions of $10 \times 20 \mathrm{~cm}$, with a volume capacity of approximately $700 \mathrm{~mL}$. The substrates used were sand of medium granulometry and the Golden $\mathrm{Mix}^{\circledR}$ coconut fiber (Amafibra).

The seedlings conducted in coconut fiber were daily irrigated with water and every fifteen days with nutrient solution (Table 1) and the seedlings conducted in the sand were daily irrigated with nutrient solution (Table 1), according to the crop demand. The nutrient solution used was formulated to meet the needs of the olive tree crop, according to recommendations of Schuch \& Peil (2012).

The evaluations carried out were: the survival percentage of seedlings, the length of the area and the length of the roots. The height determination started after 60 days of the seedlings being transplanted for the two substrates. The evaluations were carried out every 30 days. The height of the stems was evaluated through a ruler graduated in centimeter $(\mathrm{cm})$, measuring the distance between the cervix and the apex of the seedling. At the end of the experiment, the root length was evaluated. The root length was obtained by measuring the distance from the cervix to the apex of the root. The measurements were made with a ruler graduated in centimeter $(\mathrm{cm})$.

As a result, the substrate coconut fiber showed the best results for the development of olive trees of Arbequina cultivar when compared to the sand substrate (Figure 10). 


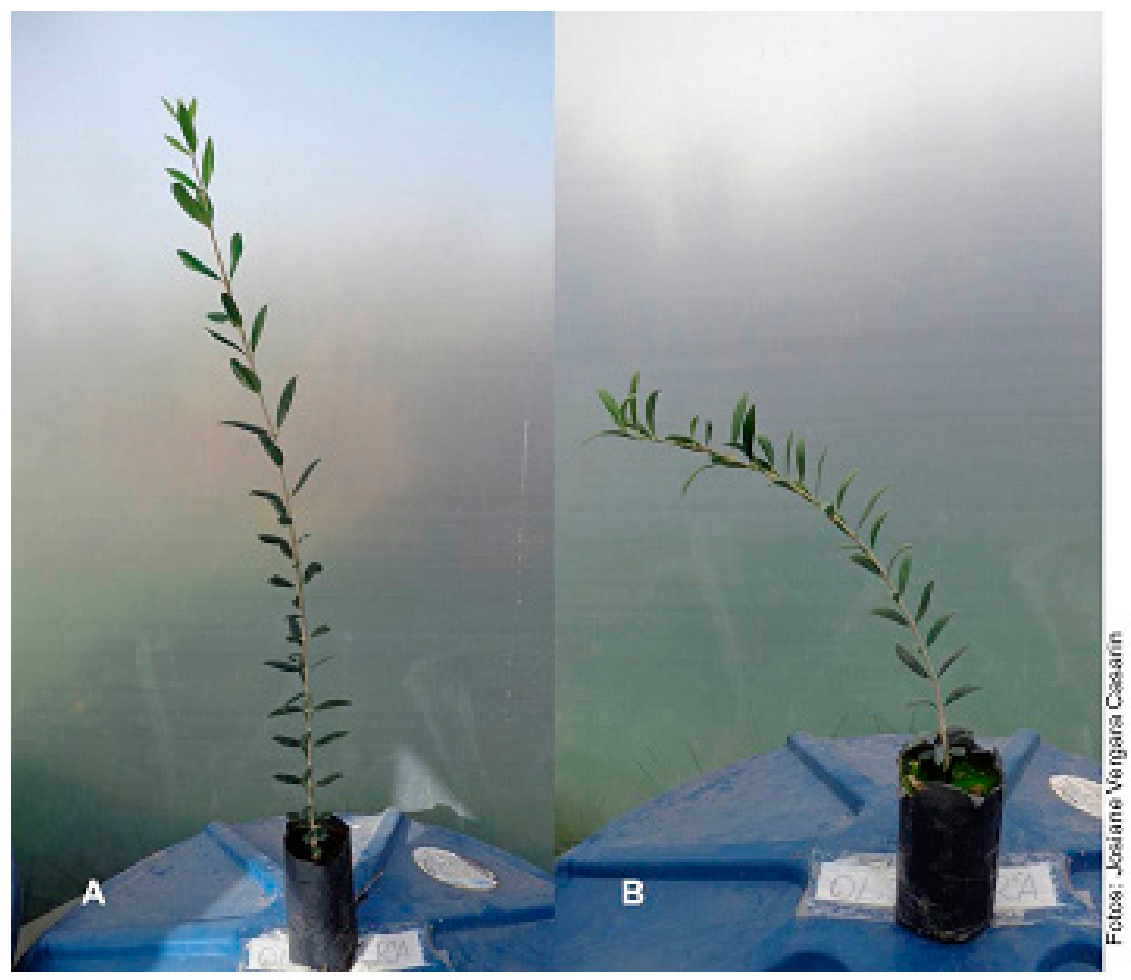

Figure 10 - Vegetative development of olive tree of Arbequina cultivars from minicuttings: A) Coconut fiber and B) Sand

There is a vast knowledge about the characteristics of the olive tree for use as fruit. The same cannot be said for the production destined for the market of ornamental plants. However, the dark green coloration on the adaxial surface and grayish on the abaxial leaves; the color and morphology of the flowers; the color and shape of the fruits, as well as the longevity of the plant can be indicative advantages of its plantation aiming at the use as ornamental plant. As a result of these aspects, SILVA et al. (2016) evaluate its use as an ornamental plant, being a promising and innovative alternative for the diversification in the areas of fruit growing and floriculture, allowing to the producers a new income option, given the growing demand for new products in the consumer market. However, there is no information regarding the cultivation of the olive tree in a container, evidencing the need for research.

\section{Conclusions}

Currently, the Laboratory of Propagation of Fruit Plants of the Federal University of Pelotas, from the continuity to the study developed by Casarin (2015), is maintaining the olive clonal garden of Arbequina cultivar and carrying out evaluations regarding the productivity of ministumps during successive collections, in semihydroponic and conventional cultivation systems and the rooting of these minicuttings, collected at different seasons of the year. At the beginning of 2014, new experiments were installed with the Maria da Fé and Grappolo 541 cultivars in order to evaluate the same parameters described above (ministumps productivity and rooting at different seasons of the year and in different cultivation systems). In micropropagation, with data obtained from in vitro establishment by Moreira (2014), new experiments were carried out regarding the multiplication phase of plants in vitro. However, it has not yet been possible to obtain an efficient protocol for this crop because the olive tree has a strong apical dominance and problems related to oxidation. In this way, the researchers that are being carried out seek to generate knowledge about the best way of propagating and conducting of this fruit tree.

\section{Acknowledgements}

We would like to thank the Coordination of Higher Education Personnel Improvement (CAPES) for granting the scholarships.

The Foundation for Research Support of the State of Rio Grande do Sul (FAPERGS) and National Research Council (CNPq) for the financial support. 


\section{References}

CAPPELLARO, T.H. Produção de mudas de oliveira em sistemas de cultivo sem solo. 2013. 105f. Tese (Doutorado Programa de Pós-Graduação em Agronomia). Universidade Federal de Pelotas, Pelotas, 2013.

CASARIN, J.V. Enraizamento de miniestacas de oliveira (Olea europaea $\mathrm{L}$.) coletadas em minijardim clonal nos sistemas de cultivo sem solo e convencional em diferentes épocas do ano. 2015. 128f. Tese (Doutorado) Programa de Pós-Graduação em Agronomia. Universidade Federal de Pelotas. Pelotas, 2015.

FACHINELLO, J.C.; HOFFMANN, A.; NACHTIGAL, J.C. Propagação de plantas frutíferas. Brasília, DF: EMBRAPA, 2005. 221p.

MELO, L.A. de.; XAVIER, A.; PAIVA, H.N. de.; BORGES, S.R. Otimização do tempo necessário para o enraizamento de miniestacas de clones híbridos de Eucalyptus grandis. Revista Árvore, Viçosa, MG, v.35, n. 4, p.759-767, 2011.

MOREIRA, R.M. Estabelecimento in vitro de cultivares de oliveira. 2014. 83f. Dissertação (Mestrado) - Programa de Pós-Graduação em Agronomia, Universidade Federal de Pelotas, Pelotas, 2014.

OLIVEIRA, A. F. de.; PASQUAL, M.; CHALFUN, N. N. J.; REGINA, M. A. de.; DEL RIO RINCÓN, C. Influência do número de nós em estacas semilenhosas de oliveira (Olea europaea L.) no enraizamento sob câmara de nebulização. Ciência e Agrotecnologia, Lavras, v.27, n.2, p.332-338, 2003.

OLIVEIRA, A. F. de.; ANTUNES, L. E. C.; SCHUCH, M. W. Caracterização morfológica de cultivares de oliveira em coleção e considerações sobre o seu cultivo no Brasil. Informe Agropecuário, Belo Horizonte, v.27, n.231, p.55-62, 2006.
OLIVEIRA, A. F. de.; VIEIRA NETO, J.; VILLA, F.; SILVA, L.F.O. da. Espaçamento entre plantas no desempenho de jardim clonal de cultivares de oliveira. Scientia Agraria, Piracicaba, v.11, n.4, p.317-322, 2010.

OLIVEIRA, M.C.; RAMOS, J. D.; PIO, R.; CARDOSO, M. G. Características fenológicas e físicas e perfil de ácidos graxos em oliveiras no sul de Minas Gerais. Pesquisa Agropecuária Brasileira, Brasília, DF, v.47, n.1, p.30-35, 2012.

SCHUCH, M.W.; PEIL, R. M.N. Soilless cultivation systems: a new approach in fruit plants propagation in southern Brazil. Acta Horticulturae, The Hague, v. 952, p.877-884, 2012.

SILVA, J. B.; RAMM, A.; MOREIRA, R. M.; SCHUCH, M. W., ASSIS, A. M. Produção de oliveira em vaso para fins ornamentais. In: CONGRESSO BRASILEIRO DE FRUTICULTURA "FRUTEIRAS NATIVAS E SUSTENTABILIDADE, 24., 2016, São Luis. Anais... Campos dos Goytacazes: Sociedade Brasileira de Fruticultura, 2016.

VIEIRANETO, J.; CANÇADO, G. M.A. de.; OLIVEIRA, A. F. de.; MESQUITA, H. A. de.; LÚCIO, A. D.; SILVA, L. F. O. da. Fertilizantes na produção de mudas de oliveira 'Arbequina'. Scientia Agraria, Piracicaba, v.11, n.1, p.049-055, 2010.

WREGE, M. S.; COUTINHO, E. F.; PANTANO, A. P.; JORGE, R.O. Distribuição do potencial de oliveiras no Brasil e no Mundo. Revista Brasileira de Fruticultura, Jaboticabal, v.37, n.3, p.656-666, 2015

ZIETEMANN, C.; ROBERTO, S.R. Produção de mudas de goiabeira (Psidium guajava) em diferentes substratos. Revista Brasileira de Fruticultura, Jaboticabal, v.29, n.1, p.137-142, 2007. 